\title{
Immovable Cultural Heritage at Risk: Past - Present - Future
}

\author{
Kurt G. Siehr*
}

\begin{abstract}
Immovable cultural heritage is still at risk of being neglected by the state responsible for heritage sites, by urban planning of big cities, and by armed conflicts around the world. Normally, because it is immovable, the international community cannot do very much. It can ban the trade of items that became movable property when detached from buildings or illegally excavated in certain protected sites. In other cases, it is the responsibility of the national state to care for cultural heritage and cultural objects. International conventions may furnish help and advice and provide for monitoring any risk to the cultural heritage of state parties.
\end{abstract}

\section{INTRODUCTION}

Immovable cultural property has been, is, and will always be at risk. Natural catastrophes, wars, and renovations have destroyed many pieces of cultural heritage, sometimes creating new cultural objects worthy of preservation. But should they be preserved? Should all efforts be made to protect these objects from any risk of being destroyed? Let us have a look into the past, present, and future of certain objects.

\section{NATURAL CATASTROPHES: POMPEII}

\section{Past}

In ancient Roman times, Pompeii, at the foot of Mount Vesuvius, as well as Herculaneum and Stabiae, were prosperous and thriving towns of more than 20,000 inhabitants. There were fora, temples, amphitheaters, magnificently decorated palaces of local nobility and, of course, shops, workshops, brothels, and houses of normal people. We do not know of any written record of ancient Pompeii.

^Universität Zürich, Switzerland, and Max-Planck-Institut, Hamburg, Germany. Email: siehr@mpipriv.de 
From excavations, and not from Edward Bulwer-Lytton, ${ }^{1}$ we know, however, that precious statues and other cultural objects were also exhibited in public fora and private palaces. In $79 \mathrm{CE}$, Mount Vesuvius erupted and the whole city of Pompeii was covered with several layers of ashes up to more than 20 meters deep. The entire old city disappeared. Pliny the Younger wrote about this disaster and gave as an eyewitness some firsthand impressions of the ancient catastrophe. ${ }^{2}$ Very soon thereafter, Emperor Titus (79-81 CE) managed to build the new city of Pompeii close to the completely destroyed old city.

Pompeii was rediscovered almost 1700 years later. In 1738, excavations started, and King Charles VII of Naples (1735-1759) stored the finds in a museum, detached frescos, and donated frescos to relatives and friends until Johann Joachim Winckelmann (1717-1768) tried to stop this unscientific attitude and required proper archaeological behavior and documentation. ${ }^{3}$ Very soon the site of Pompeii was opened to the public, and at least one of John Henry Merryman's elements of cultural property policy, "access," had been met. ${ }^{4}$

In 1997 the site of Pompeii was added to the UNESCO list of the World Cultural Heritage, showing that even archaeological sites and excavated ruins may become part of our cultural heritage and are considered worthy of protection. About 3 million tourists visit the site every year and pay about $€ 25$ million entrance fees.

\section{Present}

The present situation of the archaeological site of Pompeii can only be termed lamentable. In 2010 and 2011, heavy storms and tropical rainfalls caused great damage to the excavated ruins. They broke down and collapsed, and ancient frescos were damaged or even destroyed. Following these events, four steps were taken:

1. The Italian government passed the Legge-Decreto No. 34/2011 of 31 March 2011 in order to strengthen the supervision of the protection of the archaeological site of Pompeii. ${ }^{5}$

2. On 29 March 2012, the European Commission approved the funding of the restoration of Pompeii as an important European heritage site with an investment of $€ 105$ million. $^{6}$

3. In June 2013, the UNESCO World Heritage Committee, at its 37th session held in Phnom Penh, adopted a decision to implement the recommendations of the World Heritage Center and the International Council on Monuments and Sites (ICOMOS) reactive monitoring mission to Pompeii. ${ }^{7}$

4. Finally the Italian government approved the "Grande Progetto Pompei" by adopting the Legge Decreto no. 91/2013 of 8 August 2013 and deciding to take urgent measures to that end.

It still remains to be seen whether these joint efforts will be successful and save the archaeological site of Pompeii for future generations. ${ }^{8}$ 


\section{Future}

The open-air museum of Pompeii is special insofar as there is no need for the local population to use the site of ancient Pompeii as a dwelling place or as a professional workshop. In principle, it is a museum and should be run as such. It has, however, its specialty: Ruins are more costly to restore than modern buildings. At least three basic policies should be pursued:

1. The archaeological site should be run by local authorities and not by international organizations. These organizations may help (as does the European Commission) or give advice (as do UNESCO and ICOMOS).

2. If there is no experience with private museums, run as a trust or foundation, state authorities should be responsible, directly or indirectly, for Pompeii.

3. To give the museum directors some incentive to promote the place, entrance fees should not be transferred to the state but collected by the museum and spent for its improvement.

These policies need some explanation. Only the local state can care efficiently for archaeological sites. It has to preserve ancient ruins and ensure that they do not become "perishable" pieces of art and "ruins of modernity." The local state may, however, by concluding an international treaty, concede that a foreign state be allowed to excavate a site under the supervision of the local state. This was done, for example, in 1875 with the archaeological site of Olympia in a bilateral treaty between the Kingdom of Greece and the German Empire. ${ }^{9}$ International organizations do not employ archaeologists who can be sent abroad to do their professional work in foreign countries. These organizations may give advice but, in general, they should not support the foreign state by transferring money to that state. Money with its "fluid" character often runs into false pockets and vanishes no sooner than it has been given.

In many countries the financial support of cultural institutions is not very well organized. They have to transfer the entrance fees collected to the general budget of the central state and have to apply for support at a different department of the central government. This should be changed and the entrance fees collected should be used for the support of the collecting institution and serve as an incentive for further improving the place of and work at that institution.

\section{STATE AS GUARDIAN: ROME, PARIS, AND DRESDEN}

\section{Past}

Old cities such as Rome, Paris, and Dresden have quite a history of development, destruction, and renovation.

Rome, a small town of an Etruscan kingdom, became the capital of the Roman Empire. In late antiquity, the city of Rome was sacked by Germanic tribes. Ancient 
monuments were demolished and marble stone was burnt in lime kilns until the Roman aristocracy became interested in ancient sculpture (e.g., the sculpture "Laocoön and His Sons," excavated in 1506) and prohibited the burning of marbles. Ruins were not protected. Temples became churches (e.g., the Roman Pantheon) and ancient baths were converted into churches (e.g., the Terme di Diocleziano became the church of Santa Maria degli Angeli e dei Martiri in the Piazza della Repubblica). The Forum Romanum, once the magnificent center of Roman political, social, and religious life, the scene of many triumphal processions, became the Campo Vaccino where cows (in Italian: vacca, plural: vacce) were grazing between and under the ruins of the formerly splendid Via Sacra. Almost nobody cared for the preservation of ancient ruins. They served as a quarry. The Romans did that which had always been done in ancient times: They constructed their new buildings on the rubble of the former ones.

This habit did not change when Italy became independent and united in 1861 and the state authorities moved from Florence to the newly proclaimed Italian capital of Rome in 1871. Enormous efforts were made to change medieval and baroque Rome into a modern city with modern houses, spacious shops, and elegant galleries. ${ }^{10}$ If there had been a superintendent of ancient immovable monuments, the superintendent would have forbidden many demolitions and the destruction of various quarters. But there was none. Of the old city that vanished, we only know from the paintings of Ettore Roesler Franz (1845-1907), which depict and illustrate vanished Rome at the end of the 19th century. ${ }^{11}$ Also the monastery of Santa Maria in Aracoeli in the Piazza Venezia had to be torn down in order to build the Monumento Nazionale a Vittorio Emanuele II for the first king of the young kingdom of Italy. The construction of this Monumento started in 1885 and it was inaugurated in $1911 .^{12}$ It is close to the Palazzo Aldobrandini where the International Institute for the Unification of Private Law (UNIDROIT) is located and where John Henry Merryman wanted to improve the UNIDROIT Convention of 1995 on Stolen or Illegally Exported Cultural Objects. The Monumento Nazionale is sometimes derogatorily called "macchina da scrivere" or "torta nuziale."

Paris is another European capital with a different, but similar history. Of Celtic origin, Lutetia became a Roman town and escaped invasions and destruction by enemies in warfare and in revolutions. The Bastille was torn down on 14 July 1789. But the important changes were brought about by George-Eugène Haussmann (1809-1891), who was nominated prefect of the Seine department. In this capacity, he created modern Paris with straight and wide avenues connecting the terminals of Paris, demolishing small quarters in order to establish a modern city with streetlights, water supply, and drainage. ${ }^{13}$ The execution of his urban planning was later imitated everywhere.

But Haussmann was not the only person to revolutionize modern architecture and urban planning. The civil engineer Alexandre Gustave Eiffel (1832-1923) was asked to construct a big tower of more than 300 meters high for the 1889 Universal Exposition to be held in Paris. On 14 February 1887, two years before the tower 
was inaugurated, some people published the protest note "Les artistes contre la tour Eiffel" in the newspaper Le Temps: "We come, we authors [i.e., Alexandre Dumas, fils; Guy de Maupassant], painters [i.e., Jean-Louis Meissonier], sculptors, architects, lovers of the beauty of Paris [i.e., the composer Charles Gounod] which was until now intact, to protest with all our strength and all our indignation, in the name of the underestimated taste of the French, in the name of French art and history under threat, against the erection in the very heart of our capital, of the useless and monstrous Eiffel Tower, which popular ill-feeling, so often an arbiter of good sense and justice, has already baptized the Tower of Babel." 14 This protest note was issued in vain: The tower was erected, not torn down after the Universal Exhibition ended, only to become a very useful part of French telecommunication technology and one of the most important landmarks of Paris in the 20th century, visited by more than 6 million tourists per year.

The German city of Dresden has had quite a different history. Dresden, much younger and much smaller than the Italian and French capitals, became the capital of the Electorate of Saxony in the 14th century. Three hundred years later, Elector August II the Strong made the city a center of art, architecture, business, and commerce. The city itself did not suffer considerably from the Thirty Years War (16181648), the Seven Years War (1756-1763), or World War I (1914-1918). Plagues and fires, however, damaged the city and its inhabitants. The skyline of the city was still the same, painted as "Canaletto View" by Bernardo Bellotto, who was called Canaletto (1722-1780).

In World War II, the city was severely damaged by bombs and the ensuing firestorm. Large parts of the formerly splendid city lay in ruins, and thousands of people were killed. Until the reunification of Germany in 1990, the East German government saved, reconstructed, and preserved the Opera House (Semper-Oper), the State Gallery, and the Dresden Zwinger, as well as the Catholic Hofkirche. But much remained to be done in the future because of lack of money.

Summarizing the history of cities, three points may be in common to all of them.

1. Cities grew and developed in a kind of "productive destruction" as the art historian Horst Bredekamp named this phenomenon. ${ }^{15}$

2. Town planning in ancient cities came rather late, was poorly enforced, and hardly anybody cared for the protection of old buildings and living quarters.

3. Only precious movables (e.g., sculptures) were saved, collected, and preserved.

\section{Present}

Today all big cities have local town planning directives that have to be complied with when adding new buildings to the city or replacing old buildings with new ones. Cities pursue different policies. Some prohibit the building of skyscrapers in the very city center in order to escape the situation in cities such as New York or Frankfurt/Main, where old churches and cathedrals are hidden behind big 
buildings or look like St. Patrick's Cathedral in New York or the Imperial Cathedral of St. Bartholomäus in Frankfurt/Main. In Hamburg, Zürich, and other cities, this is not permitted, and big office buildings have to be erected in quarters outside the old city.

Another phenomenon emerged in Germany. Instead of newly planned buildings of modern style and appearance, many German cities, after World War II, preferred to reconstruct the old buildings, especially old museums, castles, and palaces, in an effort to give their city the same appearance as before the war. Two examples may suffice. The first concerns the Frauenkirche in Dresden. The church was destroyed in World War II. The remaining ruins were designated as a memorial against war and destruction. Even before the reunification of Germany, plans were discussed to reconstruct the church as a symbol of peace and reconciliation by adding its cupola to the skyline of the city and using the interior for services of the Protestant congregation of Dresden. The typical debate in such cases of reconstruction arose: Since there cannot be a correct reconstruction, it should not be done. But the opposite view prevailed. The majority of donors from all over the world, having collected more than $€ 100$ million, which was more than $60 \%$ of the reconstruction costs of $€ 180$ million, wanted to again have the church to symbolize Dresden as an important, industrious, and cultural center of Germany. On 30 October 2005, the Frauenkirche of Dresden was officially inaugurated. The other example is the Town Castle (Stadtschloss) of Berlin. The big building on and opposite "Museum Island" was a baroque palace designed for the imperial family, as well as official representation and imperial administration. After World War I and the abdication of the German Emperor, the Stadtschloss housed different offices and institutions, as well as the Kaiser Wilhelm Institute for International Law (now in Heidelberg) and for Comparative and International Private Law (now in Hamburg). It was severely damaged during World War II and torn down completely by the East German government in 1950. However, soon after German reunification, private and public movements supported the reconstruction of the Stadtschloss. The same debate arose as in the case of the Frauenkirche of Dresden, but ultimately the German Parliament decided to support the plan of the Italian architect Francesco Stella. The foundation stone of the Humboldt-Forum, as the new building will be called, was laid in 2013. The Humboldt-Forum will house museums, scientific collections, and conference halls.

Finally, the famous case of the Waldschlösschen Bridge across the river Elbe in Dresden should be mentioned. In 2004, the Dresden Elbe Valley was declared a UNESCO World Heritage Site at a time when there was already a lively discussion whether an additional bridge across the Elbe river, upstream the old one, should relieve the city of Dresden from inner-city traffic congestion. The Green Party put forward the "bats, bugs, and boars argument" and argued that especially bats (living close to the place where the bridge was planned) should be protected and no bridge should be built. Also UNESCO disagreed and listed the Dresden Elbe Valley as an Endangered World Heritage Site in 2006. Despite this, the population 
of Dresden voted for the construction of the Waldschlösschen Bridge, and this was confirmed by court decisions. UNESCO delisted the Dresden Elbe Valley in 2009. The bridge was built and inaugurated in 2013. ${ }^{16}$

The present state of affairs can be summarized as follows:

- Currently, every city regulates urban planning and monument protection. These regulations are of a purely local nature.

- A city may, however, accept international restrictions on urban planning by submitting an application to be listed as World Heritage or as a World Heritage Site. If the city no longer wants these restrictions, such a decision should be respected and the place should be delisted.

- Regarding the problem of reconstructing old or destroyed buildings, the ancient argument must first be resolved: Which is to be considered the old version of the building? Is it the original one or the one that existed immediately before destruction?

\section{Future}

The future of the state as an effective guardian of cultural property does not seem to be very promising. Three problems may be mentioned and evaluated.

The first problem may be described as follows: Rural exodus - huge megalopolis. In recent years, cities, especially in Asia, have become ever bigger. Rural exodus has increased and problems in the cities can no longer be solved. The phenomenon of rural exodus has been known since the Middle Ages in many European countries. The reasons for this movement were to some extent different: Rural life was primitive and burdensome, whereas life in town made one free from feudal bonds; as a citizen one could acquire a privileged position, and commercial activities were easier to carry out in towns than in rural areas. This has changed very much. People from rural areas of local and foreign countries do not have professions needed in the big cities. They are laborers and cannot find jobs to suit their skills. They cannot pay expensive rent for rooms or apartments, and consequently end up living in the poor districts of large cities and sometimes become criminals. Many cities cannot cope with the ensuing problems. The state cannot create jobs; this can only be done by entrepreneurs and commercial companies. If the state creates public jobs, it may go bankrupt and have to fire the employees that do not fit their jobs. Even decentralization of office buildings is no solution because rural refugees do not have the skills to become proper employees. But if the big cities provide for these people, this policy would attract even more of them. Therefore, cities refrain from providing housing for low-educated refugees from rural areas.

The second problem may be called Smog - town air creates illness. This problem is, to an extent, the result of the former one: Big cities create more traffic and more industry, which in turn, create more pollution, and intensive air pollution is unhealthy. But not only citizens suffer, also monuments have to be removed 
to safe places and be replaced by copies. This has been done with Michelangelo's David in front of the Palazzo Vecchio in Florence, with the Horses of St. Marc in Venice, and with the Equestrian Statue of Marcus Aurelius on Capitol Hill in Rome. All these cultural objects had to be removed and placed in museums. Copies of them replace the originals. Other countries face the same problem and have chosen the same solution.

The last problem is that of privatization. In many European countries, the state has to protect cultural objects and immovable monuments. The reason for this engagement is different. It may be a general policy, it may be state ownership of buildings, or it may, as in German ecclesiastical law, be historically explained as "Kirchenbaulast" (the obligation of the state to maintain churches and church buildings in proper condition). However, good old times have recently come to an end, when state policies changed and austerity has ostensibly become one of the main targets of state policy. These austerity budgets also mean less or even no subsidy for museums. Hence, newly built museums and public libraries cannot be opened, or they may be closed, or they may have to cut their opening hours, or it may even lead to deaccessioning museum items in order to repair the museum building. As we know from the Detroit Institute of Arts and the insolvent city of Detroit, the closing of once-prospering institutions may also be the end of museums. Consequently, in the last few years, many countries, because of financial problems, decided to stop further subsidy of public monuments and pursue a policy of privatization of their protection. ${ }^{17}$ In other countries, less money is provided for the protection of important public monuments and for rescue excavations. Also the Kirchenbaulast has been abolished in some of the German Länder (states). The result may be that more private initiative is needed in these countries to save and maintain public monuments.

The prospects for the future may be summarized as follows:

- The future of big cities is a local problem to be solved locally.

- The international community can prepare some guidelines and policies (United Nations Climate Change Conferences) and formulate proposals.

- However, the implementation of these proposals has to be done locally, under the responsibility of the single state.

\section{ARMED CONFLICT: SARAJEVO, BAGHDAD, AND ALEPPO}

\section{Past}

Sarajevo: Yugoslavia became a state very late. Romans, Turks, Hungarians, and Austrians left their traces in the country. After World War I, it was formed as a kingdom by a merger of different provinces with a population that belonged to different denominations, formerly governed or supervised by the Austro-Hungarian Empire. After Tito passed away in 1980, tension between Serbia and other parts of 
the country intensified, finally leading to civil war. In 1991, more than 20 years ago, Serbian troops besieged the Croatian city of Dubrovnik and destroyed some of its historical monuments. This was completely unnecessary, and the Serbian Lieutenant General Pavle Strugar was convicted by the International Criminal Tribunal for the former Yugoslavia (ICTY) in The Hague for destroying cultural objects. ${ }^{18}$

The Bosnian War was fought in 1992-1996. In August 1992, while the city of Sarajevo was besieged, Serbian troops destroyed the library of Sarajevo and most of the books collected in this library. This bombing was completely unnecessary. It was a sheer attack on the cultural heritage of the Bosnian people living in Sarajevo and Bosnia. Slobodan Milošević, the last president of the Republic of Yugoslavia, was not assassinated by his enemies, but in 2006, died of a heart attack in prison in The Hague, where he had been accused of war crimes and stood trial before the ICTY. Yugoslavia finally split into seven different countries (Bosnia-Herzegovina, Croatia, Kosovo, Macedonia, Montenegro, Serbia, and Slovenia). Two of them are already members of the European Union: Croatia and Slovenia.

Baghdad: Mesopotamia is part of the Fertile Crescent, the land in and around the Tigris and Euphrates Rivers. It is the cradle of one of the oldest known civilizations and an El Dorado for archaeologists. The Code of Hammurabi (about 1772 вСе) was found in Babylon (now in the French Louvre); the Hanging Gardens of Semiramis were supposedly located in that city, and the Ishtar Gate (now in the Vorderasiatische Museum, Berlin) was excavated in Babylon. The National Museum of Iraq in Baghdad was looted, excavation sites were no longer guarded, and anybody could take the opportunity to hunt for hidden treasures without proper documentation. Antiquities from Iraq were smuggled to foreign countries, bringing the Security Council of the United Nations to pass Resolution 1483 of 22 May 2003, requiring all member states to "take appropriate steps to facilitate the safe return to Iraqi institutions of Iraqi cultural property and other items of archaeological, historical, cultural, rare scientific, and religious importance illegally removed from the Iraq National Museum, the National Library, and other locations in Iraq ..., including by establishing a prohibition on trade in or transfer of such items." 19 The European Union reacted quickly. Some weeks later, it adopted the directly applicable Council Regulation (EC) No. 1210/2003 of 2 July 2003, prohibiting in its Article 3, Section 1 the import, export, and "the dealing in Iraqi cultural property and other items of archaeological, historical, cultural, rare scientific and religious importance..."20 Many items have been returned, but rather often, it could not be shown that the objects had been illegally exported and not legally obtained from old collections. ${ }^{21}$

Aleppo: In December 2010, Tunisian people started the revolution against autocratic heads of state and sent Prime Minster Ben Ali into exile. In January 2011, demonstrations against President Mubarak erupted in Egypt, ending with his stepping down and standing trial for accusations of not giving orders to stop the killing of peaceful demonstrators. In 2013, mass protests also erupted against the elected Muslim Brotherhood party, which was subsequently ousted by the military, 
with President Morsi being arrested to stand trial on charges of inciting deadly violence. During the 2011 revolution, the National Egyptian Museum in Cairo was also attacked and items may have been stolen. ${ }^{22}$

In February 2011, Libya followed suit, its ruler Gadhafi was killed, and a new government established. Civil war in Syria started in March 2011. The war is still going on. Aleppo, the old city with the citadel, was bombed and several monuments were destroyed during the battle between the rebels and the troops of Assad, the head of state. ${ }^{23}$

What has been called the "Islamic Spring," a time of hope for democracy and self-determination in African states and states of the Near East, turned out to be a disaster for the local cultural heritage and the civilized dealing with national treasures and museums. Only a small portion of the population cared for the antiquities and tried to preserve them. Apart from the intentional destruction of Christian churches and other buildings, the devastation was not due to hatred and vandalism against religious groups, but to simple avarice for quick money and income by ways not formerly allowed in times of peace.

Summarizing these recent events, the following can be said:

- In recent wars, which to a large extent arose from interior tensions, the rules provided in the 1954 Hague Convention were not followed by the belligerent parties.

- No "monuments men" were present to take care of cultural treasures.

- Sometimes private mercenary armies, such as Blackwater, do not seem to have had any preparation for the protection of cultural objects. ${ }^{24}$

\section{Present and Future}

The present situation does not look very good. Armed conflicts arise in many countries, religious battles are fought in some parts of this world, and there seems to be no end to these disputes between states, between different populations of the same state, and between some religious groups and denominations in some parts of the continents.

The following recommendations may be made:

- Since armed conflicts cannot be suppressed, cultural heritage sites should be better protected than before. The battles no long take place only in the streets. Air raids are conducted, and even in these cases, more efficient protection is necessary.

- Iconoclasm is still practiced, but commanders should be aware that destruction of cultural objects is severely prohibited.

- Whether there will be "monuments men" in the future is doubtful as who wants to be part of a suicide mission? But trade in cultural objects originating in the countries of conflict should be prohibited, even if archaeological objects, once illegally excavated, are lost for research in their exact provenance and context. 


\section{SUMMARY}

Immovable cultural heritage is still at risk: Archaeological sites may be neglected, big cities may suffer under urban planning, and entire countries, their cities, and monuments may be destroyed by armed conflict.

1. Archaeological sites should be taken care of by the local state authorities. They must assume the responsibility for their protection. International organizations and institutions can give advice and provide help. However, they should not transfer money but rather help by people paid by sponsors.

2. Cities may pursue a "productive deconstruction" rather than transformation into an open-air museum. They decide whether destroyed buildings should be reconstructed or replaced by modern buildings. The cities should decide whether local traffic is more important than being on the list of World Heritage Sites.

3. Armed conflicts destroy everything, also and especially cultural objects pertaining to the enemy. International organizations may help to minimize the damage done to cultural sites and monuments. Trade barriers can be used in aid of restitution of looted cultural heritage and in helping with and organizing the reconstruction of the damaged buildings.

\section{ENDNOTES}

1. In 1834, Bulwer-Lytton (1803-1873) published the novel "The Last Days of Pompeii."

2. See Plinius, Epistulae, Book 6, Letter 16.

3. Parslow, Rediscovering Antiquity, 215 et seq.; Haupt, Johann Winckelmann, 95 et seq.

4. Merryman, "The Public Interest in Cultural Property," 355 et seq., 360; and in Merryman, Thinking about the Elgin Marbles, 94-120, at pp. 112 et seq., 117.

5. See Art. 2 of this Legge Decreto in Diritto Comunitario degli Scambi Internazionali 52 (2013): 718. This Decree was approved and converted into the Legge di conversione no. 75 of 26 May 2011, Gazzetta Ufficiale della Repubblica Italiana no. 122 of 27 May 2011.

6. IP/12/328 of 29 March 2012.

7. Decision 37 COM 7B.77, in Diritto Comunitario degli Scambi Internazionali 52 (2013): 717.

8. See Migliorati, "Il sito archeologico di Pompei."

9. See the Convention du 13/25 Avril 1875 relative à des fouilles archéologiques à entreprendre sur le territoire de l'ancienne Olympie, (German) Reichsgesetzblatt 1875, pp. 241-245. Regarding this Convention, see also Kalpaxis, "Die Vorgeschichte und die Nachwirkungen des Olympia-Vertrages aus griechischer Sicht."

10. Bauer, Rom im 19. und 20. Jahrhundert. Konstruktion eines Mythos, 76 et seq.

11. Jannattoni, Roma sparita negli acquarelli di Ettore Roesler Franz.

12. See the exhaustive book of Rodiek, Das Monumento Nazionale Vittorio Emanuele II. in Rom, 34 et seq.

13. See Jordan, Transforming Paris.

14. The original French version of the protest can be found at http://fr.wikisource.org/wiki/ Protestation_des_artistes_contre_la_tour_de_M._Eiffel_du_14_f\%C3\%A9vrier_1887. See also Kluy, Der Eiffelturm, 89 et seq. 
15. Bredekamp, Sankt Peter in Rom.

16. Comprehensively to this story see Schorlemer, "Compliance with the UNESCO World Heritage Convention."

17. Olivi, "Beni pubblici tra privatizzazioni e riscoperta dei beni comuni."

18. ICTY, 31 January 2005 (Prosecutor v. Pavle Strugar), Case IT-01-42-T. On this affair see Noyes, The Politics of Iconoclasm, 145 et seq.

19. Sect. 7 of Resolution 1483 (2003), adopted by the Security Council at its 4761st meeting on 22 May 2003.

20. Council Regulation (EC) No 1210/2003 of 2 July 2003 concerning certain specific restrictions on economic and financial relations with Iraq and repealing Regulation (EC) No 2465/96, O.J. L 169, p. 6 et seq. (8 July 2003).

21. Martin Bailey, "Decade of Conflict Takes Its Toll," The Art Newspaper, March 2013: 7; Müller-Karpe, "Antikenhandel."

22. Herzog and von Pilgrim, "Unwiederbringliche Verluste"; Gary Shaw, "Egyptians Tweet to Save Their Heritage from Looting," The Art Newspaper, September 2013, 1 and 10; Francesco Tiradritti, "Devastazioni. L'arte millenaria di Egitto e Siria nella furia di guerra incivili," Il Giornale dell'Arte, September 2013, 1 and 4.

23. Maureen Marozeau, "Le patrimoine syrien, l'autre victime de la guerre civile," Le Journal des Arts, 6-19 September 2013, 44; Fabian von Poser, "Schutt und Asche. Der Bürgerkrieg bedroht auch Syriens Kulturschätze," Frankfurter Allgemeine Sonntagszeitung, 13 October 2013, part V, p 2.

24. Desseler, Krieg als Dienstleistung, 142 et seq.; Scahill, Blackwater; Scahill, Dirty Wars.

\section{BIBLIOGRAPHY}

Bauer, Franz J. Rom im 19. und 20. Jahrhundert. Konstruktion eines Mythos. Regensburg: Pustet, 2009.

Bredekamp, Horst. Sankt Peter in Rom und das Prinzip der produktiven Zerstörung: Bau und Abbau von Bramante bis Bernini. Berlin: Wagenbach, 2008.

Bulwer-Lytton, Edward. The Last Days of Pompeii. London: Bentley, 1834.

Desseler, Rolf. Krieg als Dienstleistung. Private Militärfirmen zerstören die Demokratie. 3rd ed. Berlin: Links, 2008.

Haupt, Klaus-Werner. Johann Winckelmann. Begründer der klassischen Archäologie und modernen Kunstwissenschaften. Weimar: Weimarer Verlagsgesellschaft, 2014.

Herzog, Samuel, and Cornelius von Pilgrim. "Unwiederbringliche Verluste. Wie stark gefährdet sind die archäologischen Denkmäler Ägyptens?” Neue Zürcher Zeitung. Internationale Ausgabe 2 (September 2013): 21.

Jannattoni, Livio, ed. Roma sparita negli acquarelli di Ettore Roesler Franz. Roma: Newton Compton, 1988. Jordan, David P. Transforming Paris. The Life and Labors of Baron Haussmann. New York: Free Press, 1995.

Kalpaxis, Thanassis. "Die Vorgeschichte und die Nachwirkungen des Olympia-Vertrages aus griechischer Sicht.” In Olympia 1875-2000. 125 Jahre Deutsche Ausgrabungen, edited by Helmut Kyrieleis, 19-30. Mainz: Zabern, 2002.

Kluy, Alexander. Der Eiffelturm: Geschichte und Geschichten. Berlin: Matthes \& Seitz, 2014.

Merryman, John Henry. “The Public Interest in Cultural Property.” California Law Review 77 (1989): 339-64. 
Thinking about the Elgin Marbles: Critical Essays on Cultural Property, Art and Law. The Hague, The Netherlands: Kluwer Law International, 2000.

Migliorati, Claudia. "Il sito archeologico di Pompei a rischio di cancellazione dalla lista del Patrimonio Mondiale." Diritto Comunitario degli Scambi Internazionali 52 (2013): 723-47.

Müller-Karpe, Michael. “Antikenhandel./. Kulturgüterschutz.” Kunst und Recht 12 (2010): 91-94.

_. "Antikenhandel./. Kulturgüterschutz - Fortsetzung von KUR 2010, 91 ff." Kunst und Recht 13 (2011): 61-67.

Noyes, James. The Politics of Iconoclasm. Religion, Violence and the Culture of Image Breaking in Christianity and Islam. New York: Tauris, 2013.

Olivi, Marco. "Beni pubblici tra privatizzazioni e riscoperta dei beni comuni." Amministazione In Cammino (LUISS University, Rome, 2014), ISSN 2038-3711.

Parslow, Christopher Charles. Rediscovering Antiquity. Karl Weber and the Excavation of Herculaneum, Pompeii and Stabiae. Cambridge: Cambridge University Press, 1995.

Plinius, C. Caecilius Secundus (the Younger). Epistulae. Sämtliche Briefe. Stuttgart: Reclam, 2010.

Rodiek, Thorsten. Das Monumento Nazionale Vittorio Emanuele II. in Rom. Frankfurt/Main: Lang, 1983.

Scahill, Jeremy M. Blackwater: The Rise of the World's Most Powerful Mercenary Army. New York: Serpent's Tail, 2008.

Dirty Wars: The World Is a Large Battlefield. New York: Serpent's Tail, 2014.

Schorlemer, Sabine von. "Compliance with the UNESCO World Heritage Convention: Reflections on the Elbe Valley and the Dresden Waldschlösschen Bridge." German Yearbook of International Law 51 (2008): 321-90. 